This document is downloaded from DR-NTU (https://dr.ntu.edu.sg) Nanyang Technological University, Singapore.

After the Facebook revolution : whither Egypt?

Mushahid Ali

2011

https://hdl.handle.net/10356/94587 


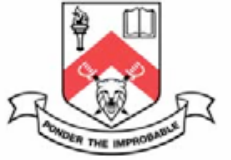

S. RAJARATNAM SCHOOL

OF INTERNATIONAL STUDIES

A Graduate School of Nanyang Technological University

\section{RSIS COMMENTARIES}

RSIS Commentaries are intended to provide timely and, where appropriate, policy relevant background and analysis of contemporary developments. The views of the authors are their own and do not represent the official position of the S.Rajaratnam School of International Studies, NTU. These commentaries may be reproduced electronically or in print with prior permission from RSIS. Due recognition must be given to the author or authors and RSIS. Please email: RSISPublication@ntu.edu.sg or call (+65) 67906982 to speak to the Editor RSIS Commentaries, Yang Razali Kassim.

No. 22/2011 dated 15 February 2011

\section{After the Facebook Revolution: Whither Egypt?}

By Mushahid Ali

\section{Synopsis}

After the ouster of President Mubarak by the Tahrir Square revolution the Army has taken over control. Given the popular confidence in it will the Army retain its hold and produce the next president of Egypt?

\section{Commentary}

The 18-day Facebook uprising in Egypt which culminated in the 11 February ouster of President Hosni Mubarak has been hailed as the triumph of the people over a despotic regime. However Mubarak handed over the running of the Egyptian government to a Supreme Council of the Armed Forces headed by Field Marshal Tantawi, Deputy Prime Minister and Defence Minister.

This military council is to arrange for the transfer of authority to a civilian government to be elected under a reformed constitution within a year. The cabinet of Prime Minister Ahmed Shafiq, hastily formed by Mubarak before his departure, will continue until a new cabinet is named. The future of the newly appointed vicepresident Omar Suleiman, to whom Mubarak had earlier handed over some of his powers, is not clear. The current People's Assembly, whose election last year has been challenged as fraudulent, is to be dissolved and fresh elections called under the reformed constitution.

\section{Unanswered Questions}

The Egyptian Revolution in Tahrir Square may have succeeded in driving President Mubarak from office, but it has raised questions about the future direction of the country. Will the committee set up to reform the constitution include any representatives of the youthful Friends of Facebook who led the uprising? Will new political parties be allowed, including the Muslim Brotherhood? Will there be a leadership role for the armed forces?

Foreign observers have assessed that the military has emerged as the real winner of the people's uprising in Egypt. Some Western observers fear that the alternative to military rule is an Islamic theocracy. Others suggest that Egypt could follow the Turkish model where the military stays in the background while an elected Islamic party runs the government along secular lines.

The Egyptian demonstrators have hailed the role of the Army in protecting their right to demonstrate and expressed confidence that the Army will pave the way for restoration of democratic and fair elections to elect a new government. The Army has pledged to fulfil all the demands of the people in making the transition to a 
freely elected civilian government. However the Army has also called on the people still occupying Tahrir Square to go home and resume their normal lives. Some protesters want to stay on to make sure that the army will carry out the promised reforms.

\section{Army and Leadership}

The youthful reformists have good reason to be wary of the Army's real intentions. The Army has been in effective control of the country since the 1952 revolution which ousted the royalist regime. The Army was at the forefront of the drastic measures taken by the regime to introduce socialist policies, expropriation of private enterprises of allegedly pro-royalist Egyptians, expulsion of Western commercial firms, nationalisation of key industries and installations such as the Suez Canal, and the persecution of suspected opponents of the regime.

Under successive military presidents -- Nasser, Sadat and Mubarak -- the Army was given charge of defence industries and allowed to run its own farms and factories for producing food and supplies for the armed forces, besides homes and social amenities for its officers. Senior military officers were appointed to senior management positions in government ministries and agencies, while those of Lieutenant-General rank were appointed governors of provinces and key ministers such as defence, security and aviation.

After 40 years of leading and running the administration, the Army remains the single most capable organisation to take over the government in which civilians play subordinate or backroom roles. The Army has been the hardwire framework of Egypt while the civilian-led cabinet ran the economic and services sectors and the powerful security services kept order with their police-state methods of suppression of dissent and subversion.

\section{Army and Politics}

This situation is also the case in the political arena, which was dominated by the ruling National Democratic Party whose leading members were former military or security officers. The opposition parties were emasculated and the well organised Muslim Brotherhood was driven underground, declared an illegal organisation because it combined religion with politics.

The result, according to Egyptian scholars, was political stagnation and desultory economic growth which failed to keep pace with the exponential increase of Egypt's population. Social inequities widened with $40 \%$ of the population living below the poverty line. It is therefore not a surprise that the Facebook demonstrators, while gaining unprecedented success in mobilising popular opposition to the Mubarak regime, have not been able to put forward or identify any single leader or group who could provide an alternative leadership for a postMubarak order.

One or two veteran diplomats, like former IAEA Director-General Muhammad El Baradei, and Arab League Secretary-General and former foreign minister Amr Mousa, were touted as possible presidential candidates. However their ground support and political organisation is doubtful. The leading inspiration of the Facebook revolution Wael Ghoneim, a Google marketing executive, has disavowed any political ambitions. So has the Muslim Brotherhood.

\section{Irony of the Revolution}

It is ironic that the protesters had to look to the Army to provide the leadership for the transition to a new order. They should not be surprised if in the process the Army puts forward its own candidates for leading positions in the new government. Although the Army has pledged to make constitutional reforms to ensure free and fair elections, the way would be open for some reformist members of the old ruling party, the NDP, or the armed forces, running as independents in the president elections. Given the popularity of the Army one should not be surprised if one of the Council of Generals is elected as the next president of Egypt.

The people who elect him can only hope that the next president will bring into his government representatives of a broader segment of the population and appoint as ministers men and women of integrity and ability who will work for the benefit of the people and prosperity of the country as a whole. The Egyptian revolution which began in Tahrir Square has a long road ahead to its destination.

The writer is Senior Fellow at the S Rajaratnam School of International Studies, Nanyang Technological University. He spent five years in Cairo as Counsellor in the Singapore Embassy from 2005-2010. 